\title{
COMBINING GREEN BUILDING AND LEAN CONSTRUCTION TO ACHIEVE MORE SUSTAINABLE DEVELOPMENT IN SOUTH AFRICA
}

\author{
J. Watkins ${ }^{1} \&$ B.P. Sunjka ${ }^{2 *}$
}

\section{ARTICLE INFO}

\section{Article details \\ Presented at the $31^{\text {st }}$ annual conference of the Southern African Institute for Industrial Engineering (SAIIE), held virtually from 5-7 October 2020. \\ Available online \\ 11 Nov 2020 \\ Contact details \\ Corresponding author \\ bernadette.sunjka1@wits.ac.za \\ Author affiliations \\ 1 School of Mechanical, Industrial and Aeronautical Engineering, University of the Witwatersrand, Johannesburg, South Africa \\ ORCID ${ }^{\circledR}$ identifiers \\ J. Watkins \\ https://orcid.org/0000-0002-3122-3202 \\ B.P. Sunjka \\ https: / /orcid.org/0000-0002-6605-6344}

DOI

http://dx.doi.org/10.7166/31-3-2426
ABSTRACT

This paper explores the synergies that exist between lean construction and green building across all the development phases in a construction project to enhance sustainable development practices in South Africa. Using a systematic literature review, 68 articles were selected and coded. The findings indicate that: (i) lean construction and green building practices, principles, techniques, tools, and technologies can be simultaneously implemented across all phases of development, and offer multidimensional benefits in each; (ii) building information modelling plays a crucial role in assisting and facilitating lean construction and green building, mutually reinforcing each other throughout a development; (iii) prefabricated construction is becoming a popular way in which lean construction and green building are interacting and supporting each other; and (iv) the interaction between lean construction and green building can help to achieve more sustainable development in South Africa.

\section{OPSOMMING}

Die sinergieë tussen lenige konstruksie en omgewingsvriendelike (groen) boutegnieke wat bestaan tydens al die ontwikkelingsfases word ondersoek. Die doel is om sodoende die volhoubare ontwikkelingspraktyke in Suid-Afrika te verbeter. Deur ' $\mathrm{n}$ sistematiese literatuurstudie is 68 artikels gekies en kodeer. Die bevindings toon dat (i) lenige konstruksie en groen boupraktyke, -beginsels, -tegnieke, -instrumente en tegnologieë gelyktydig op alle fases van ontwikkeling toegepas kan word en dat dit veelvuldige voordele vir elk inhou; (ii) die modellering van bou informasie speel 'n sleutel rol om lenige konstruksie en groen bou by te staan en te fasiliteer om sodoende mekaar te versterk; (iii) voorafvervaardigde konstruksie word 'n gewilde manier om lenige konstruksie en groen bou te vereenselwig en om mekaar te ondersteun; en (iv) die interaksie tussen lenige konstruksie en groen bou kan help om meer volhoubare ontwikkeling in Suid-Afrika te bereik.

\section{INTRODUCTION}

The construction industry represents 40 per cent of global energy consumption, 38 per cent of global greenhouse gas emissions, 12 per cent of global drinkable water use, and 40 per cent of solid waste streams [1-2]. The industry is also considered among the largest consumers of natural resources [1], [3-4]. The extraction, manufacturing, and transportation of raw materials have led to a significant reduction of resources and of biological diversity [4], [6]. High energy consumption creates acid rain, and continues to add to the negative effects of global warming [4].

The construction industry is a key and crucial player in driving economic growth in developing nations such as South Africa [6], [7]. The industry is characterised by high levels of waste, unreasonable use of water and electricity, the generation of large amounts of $\mathrm{CO}_{2}$ emissions, and countless inefficiencies increasing waste throughout the development process [7], [8]. To counteract these inefficiencies in the design, construction, and operational stages of conventional construction, green building techniques and technologies are being implemented [9], [8]. Green building is when a construction project, in its design, 
construction, and operational phases attempts to reduce or eliminate negative environmental and economic impacts, and aims to create significantly positive impacts on ecological and social environments [8-11]. Lean construction emphasises the need to reduce waste, optimise flows, and eliminate unproductive and unfruitful processes [12-13]. Green building and lean construction share a common goal, as they both strive for the efficient use of resources through the reduction of waste [13].

By reducing negative environmental, social, and economic impacts through green building, and by reducing waste in processes through lean construction, there is potential to enhance current sustainable development practices in South Africa [13]. Note that sustainable development in construction projects must be considered from a life cycle perspective, taking into account the planning, design, construction, operational, and disposal or demolition phases [14-18].

The primary objective of this research was to develop an explicit and thorough understanding of the synergies that exist between green building and lean construction throughout all stages of a construction development project. To achieve this, a systematic literature review was conducted, as it enabled the synthesis of valuable qualitative data to draw more accurate and concrete conclusions [19-20].

\section{RESEARCH METHODOLOGY}

\subsection{Research design}

The research adopted a qualitative research method in which the academic literature was analysed in a systematic and structured manner [19]. A systematic literature review is defined as a "systematic, explicit, and reproducible method for identifying, evaluating, and synthesizing the existing body of completed and recorded work produced by researchers, scholars, and practitioners" [21-23]. This approach allows for a high level of objectivity in both method and analysis, while simultaneously allowing the research to produce a comprehensive analysis of the academic literature in a selected field [24]. The review entailed collecting and obtaining accurate, clear, and relevant academic data that supported the study and assisted in addressing the objectives [20].

\subsection{Data collection}

The data collection protocol used carefully chosen qualitative means to collect the data and to ensure that the sample had depth, clarity, and quality. The correct research protocol was essential to ensure that the systematic review process was carefully planned prior to data collection and analysis. This minimised bias, improved consistency, and provided stricter research integrity and transparency [25], [60]. The data collection protocol for the systematic literature review was conducted through the steps outlined below [20], [24-27].

\subsubsection{Step 1: Initial search}

Using the primary objective of the research as a basis to establish keywords, eight phrases were created: 'Lean construction', 'Green building', 'Green construction', 'Lean principles in construction', 'Lean green construction', 'Sustainable construction supply chain'. 'Green principles in construction', 'Lean and green thinking'. 'Sustainable development' and 'sustainability' were excluded from the search terms, as 'sustainability' is intricately woven into the ideas of both 'green building' and 'lean construction'.

Table 1: Keywords and phrases to be placed in the databases

\begin{tabular}{|l|l|}
\hline Keywords or phrases created \\
\hline Lean construction & Sustainable construction supply chain \\
\hline Green building & Green principles in construction \\
\hline Green construction & Lean and green thinking \\
\hline Lean principles in construction & Lean green construction \\
\hline
\end{tabular}

Following the selection of the key phrases, all of them were placed sequentially into eight reliable and reputable multidisciplinary databases, as shown in Table 2 below. 
Table 2: Multidisciplinary databases used in the collection of the data

\subsubsection{Step 2: Collect the data}

\begin{tabular}{|l|l|}
\hline \multicolumn{2}{|l|}{ Multidisciplinary databases } \\
\hline Taylor and Francis & ProQuest \\
\hline Web of Science & JSTOR \\
\hline Scopus & EBSCOhost \\
\hline Science Direct & Wiley Online Library \\
\hline
\end{tabular}

Zotero software, which allows the storage and organisation of the qualitative data prior to coding in the computer-assisted (or aided) qualitative data analysis software (CAQDAS) NVivo, was used to collect and organise the research sample. Using Zotero, the downloaded articles were eliminated iteratively using strict inclusion and exclusion criteria, as depicted in Figure 1 below.

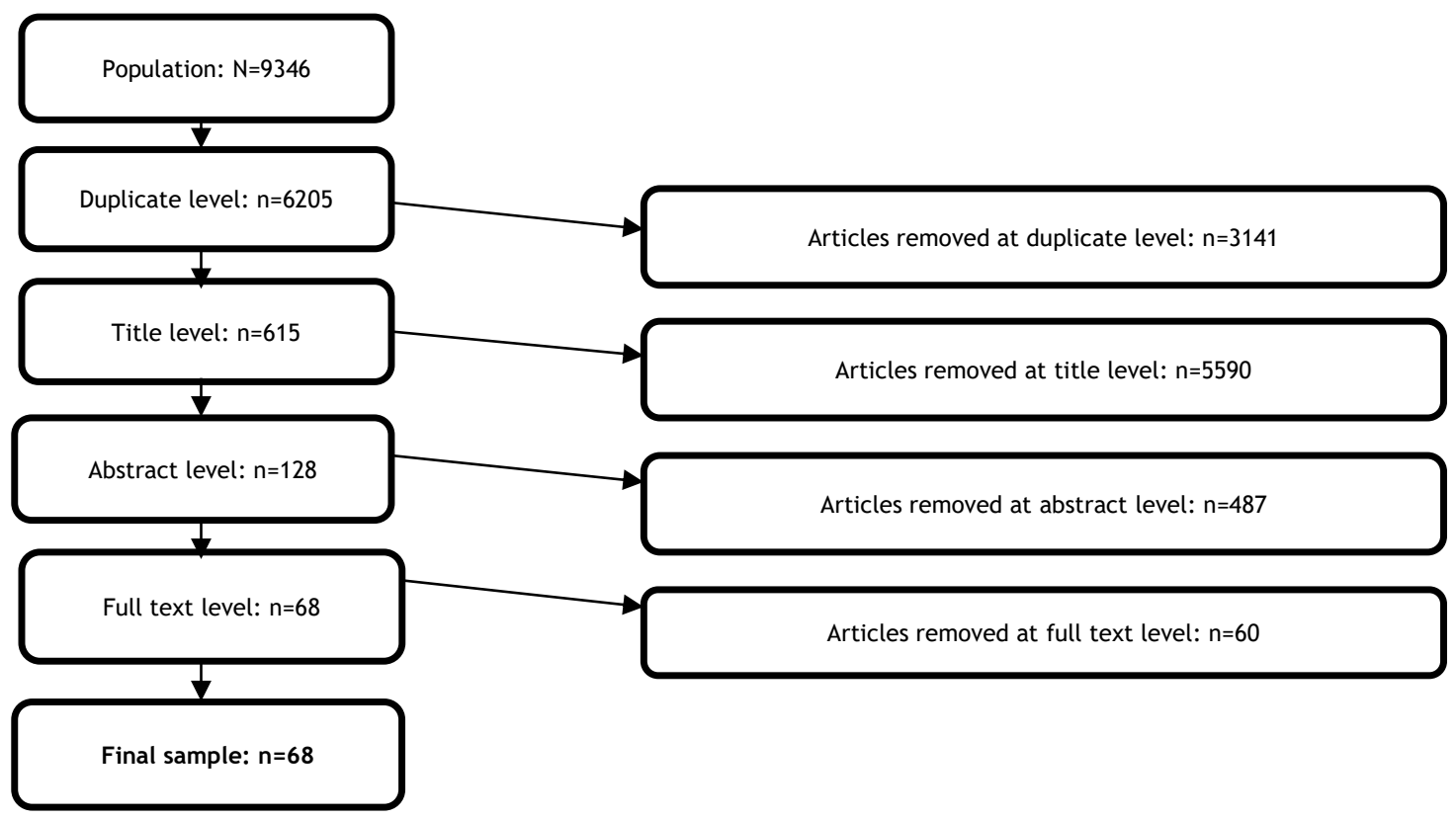

Figure 1: Process to eliminate articles

When entering the individual search terms into the databases, only articles that were written in English and that ranged from 2004 to 2019 were included in the search [19], [22]. Searching only for articles in English had the potential to increase language bias; however, the final report was written in English, and the exclusion of non-English studies had a negligible effect [22], [25]. A limited publication date allowed for the systematic review to be written using the most recent literature, thus making the findings more recent and relevant [19]. Non-academic sources (magazines, websites) were excluded in the filter settings. Journal articles, peer-reviewed articles, ongoing research articles, theses, books, book sections, and conference papers were included to avoid publication bias [22].

The initial search obtained a total of 9346 articles, which served as the population for the research. The first elimination round removed all the duplicate articles. This reduced the sample to a total number of 6 205 articles. In the next step, articles were removed based on their title. The elimination by title was assessed primarily based on the contribution of the article to addressing the primary research objective, and reduced the number of total articles to 615 articles. This was conducted twice to ensure meticulousness and thoroughness. The next stage was to eliminate by abstract. Eliminating by abstract was evaluated based on whether the article could contribute to questions addressing the primary research objective. Elimination by abstract was conducted twice with the same criteria, to ensure academic depth and rigour. This step reduced the sample to 128 articles. The final stages of elimination were based on the full text, with stricter inclusion and exclusion criteria to refine the research further. Stricter criteria (Table 3 ) were used to ensure robustness and completeness in the data set and to ensure that the critical research question was answered and that the research objective was fulfilled [19].

The full-text articles were reviewed by an external moderator to ensure that those that were selected to write the final report were critically appraised and evaluated to ensure objectivity and avoid unnecessary 
bias [25]. The external moderator also ensured that the remaining articles would achieve the goal of addressing the primary research objective. After all the elimination rounds had been completed, the final sample of 68 articles remained (see Figure 2 below). Figure 2 summarises the dates of publications that were included in the final sample, highlighting the relevance of the research and findings.

Table 3: Stricter criteria applied for elimination

\begin{tabular}{|c|c|c|}
\hline \multicolumn{3}{|c|}{ Stricter criteria applied when reading the full text } \\
\hline Green construction & $\begin{array}{l}\text { Lean principles in the design, construction, } \\
\text { operational, and demolition stages of } \\
\text { construction }\end{array}$ & $\begin{array}{l}\text { Financing lean and green } \\
\text { building }\end{array}$ \\
\hline Lean construction & $\begin{array}{l}\text { Green principles and practices in the design, } \\
\text { construction, operational, and demolition } \\
\text { stages of construction }\end{array}$ & $\begin{array}{l}\text { Investments in green } \\
\text { building }\end{array}$ \\
\hline Green building & $\begin{array}{l}\text { Holistic sustainable development (economic, } \\
\text { environmental, and social) }\end{array}$ & $\begin{array}{l}\text { Reviews on policies and } \\
\text { law }\end{array}$ \\
\hline $\begin{array}{l}\text { Sustainability through lean and green } \\
\text { practices in construction }\end{array}$ & Qualitative and quantitative research & $\begin{array}{l}\text { Failure to obtain full-text } \\
\text { article }\end{array}$ \\
\hline $\begin{array}{l}\text { Lean green supply chain management } \\
\text { on construction sites }\end{array}$ & Articles that were specific to South Africa & $\begin{array}{l}\text { The evolution of green } \\
\text { building and lean } \\
\text { construction }\end{array}$ \\
\hline $\begin{array}{l}\text { Incorporation of building information } \\
\text { modelling to achieve more sustainable } \\
\text { development }\end{array}$ & Lean and green applications in other countries & \\
\hline Prefabrication of materials & & \\
\hline
\end{tabular}

\section{Dates of publications}

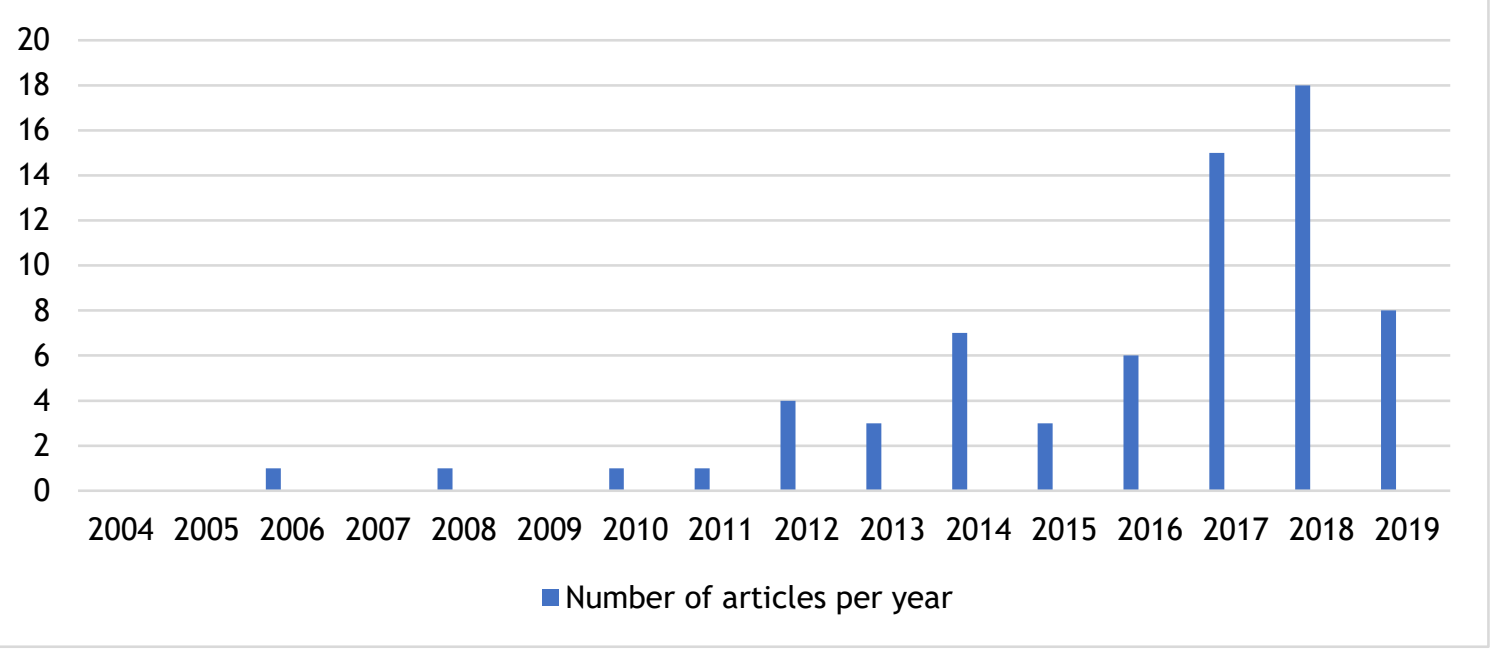

Figure 2: Dates of publications

\subsubsection{Step 3: Analysis of the data and coding}

The 68 articles were imported into NVivo CAQDAS software to be coded. NVivo is a qualitative data analysis software designed for very rich text-based information, which allows for intricate levels of analysis on large volumes of data [29]. The coding process was interpretive, and required summarising and condensing large amounts of data into a single word or phrase [30]. Each unique paragraph or line of text was assigned or coded into a unique node. The coding process allowed for the identification of patterns, where multiple authors expressed similar ideas, and where text shared commonality and was suitable to a certain node [30]. In many cases the coding filter adopted was 'descriptive coding', as the data was documented and categorised based on the variety of opinions of several authors [30]. Coding enabled the organisation and grouping of the qualitative data into nodes based on commonalities. The process of reading each full-text article from the final sample allowed for the nodes to become more refined and accurate. As the coding progressed, sub-codes were identified that were not originally considered [30]. 


\subsection{Data analysis}

The data analysis took the form of a textual narrative synthesis. This enables a data extraction format by which certain characteristics were extracted from the individual articles [19], [31]. This synthesis made use of segments of text from the articles by placing them into the designated node, which provided a foundation to write the extracted findings in the form of a narrative flowing systematic literature review [32]. Strict parameters were placed as early as possible in the analysis, such as pre-determined nodes, and only included articles that received intense objective scrutiny, ultimately minimising the subjectivity and bias. And each article was read individually, with key information then coded into the relevant nodes. Line by line coding was adopted to ensure objectivity and rigour [30].

In Table 4 below, the 'number of articles in nodes' column signifies the number of articles that are in each individual node, with 'lean and green in the preparation and design phases', 'lean and green in the construction phase' and 'lean construction' being the largest. The second column, 'extracted files from articles', signifies how many 'references' or paragraphs or sentences were placed into those nodes. It is noted that 'lean and green in the preparation and design phase', 'lean and green in the construction phase', and 'lean construction' were among the largest.

Table 4: Primary nodes in NVivo

\begin{tabular}{|l|l|l|}
\hline Name of primary node & Number of articles in nodes & Extracted files from articles \\
\hline Introduction & 31 & 128 \\
\hline Green building & 26 & 200 \\
\hline Lean construction & 40 & 302 \\
\hline $\begin{array}{l}\text { Lean and green in the preparation and design } \\
\text { phases }\end{array}$ & 45 & 283 \\
\hline Lean and green in the construction phase & 46 & 304 \\
\hline Lean and green in the operational phase & 16 & 64 \\
\hline Lean and green in the demolition phases & 10 & 47 \\
\hline
\end{tabular}

Figure 3 below provides a summary of the dates of publications that were included in the final sample, highlighting the relevance of the research and findings.

\section{Primary nodes in NVivo}

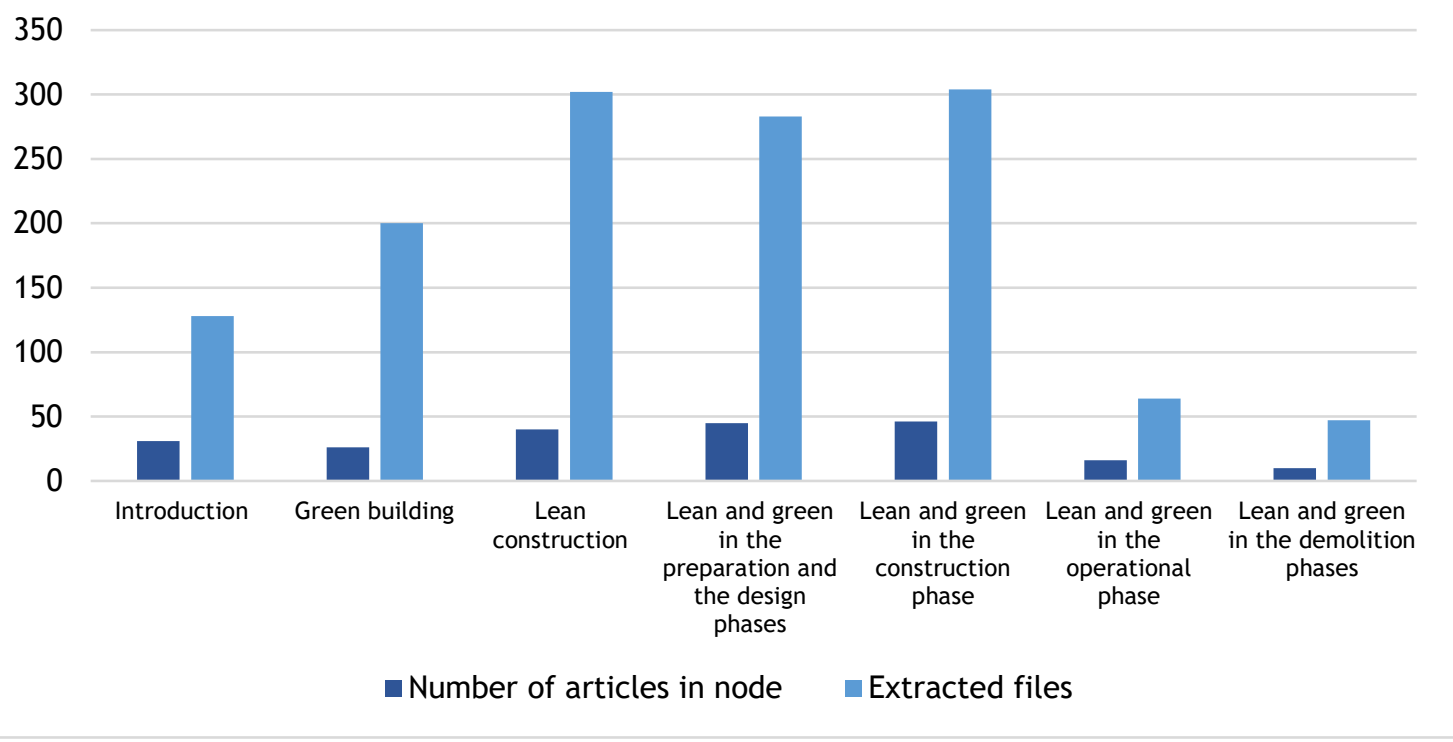

Figure 3: Primary nodes in graphical form

\subsection{Synthesis}

Subsequent to the preceding analysis, the systematic literature review was written in a narrative flowing style, journeying through each stage of a construction development. This started with 'lean and green in the preparation and design phases'; into 'lean and green in the construction phase'; into 'lean and green in the operational phase'; and last into 'lean and green in the demolition and disposal phases'. 
Concluding the synthesis, key findings and emergent findings were drawn from the review, providing an amalgamated discussion of the mutually reinforcing relationship that exists between lean construction and green building throughout every stage of a construction development. The literature highlighted that synergies do exist between both green building and lean construction, and that the two mutually reinforce each other, significantly enhancing sustainable development practices. The literature also highlighted how lean construction and green building interactions exist across the entire development life cycle. Key and unanticipated findings emerging from the systematic literature review are detailed below.

\subsection{Preparation and design phases}

First, the literature emphasised the importance of the preparation and design phase of a development, especially in minimising waste and establishing a strong foundation for the subsequent stages [33-37], [40]. In support of this, the implementation of lean construction and green building principles and practices must be done as early as possible in the project life cycle [37], [41]. The literature also emphasised that, to incorporate green building and lean construction effectively, project participants must adopt a more holistic development approach to align themselves with lean, green, and sustainability principles at every stage of the development, knowing that each stage affects the subsequent stage [14], [42], [39].

\subsection{Design practices}

Second, both lean and green building design practices support each other and mutually reinforce each other, as each will seek to optimise and address different aspects of design [37-39], [43-46]. Lean design provides insight into value creation and the reduction of waste across the life cycle of the development, while green building design seeks to address the environmental dimensions of design. These reinforcing principles enable the project team to consider the entire development, while simultaneously considering and adjusting to the social, economic, and environmental dimensions of the development [38-39], [46].

\subsection{Mutual support (lean and green)}

The support that green building and lean construction provide each other in the construction phase is important. Lean can assist in controlling and smoothing the number of activities in this phase to reduce waste, while green building principles can assist in integrating environmental considerations in reducing that waste further in an environmentally friendly manner [47-50]. And the two working together can significantly enhance the economic and social dimensions of the construction phase [38], [36], [48], [51].

\subsection{Prefabricated construction}

The use of prefabricated construction can realise both lean construction and green building benefits, outcomes, and goals [42], [47-48], [52]. Prefabrication is considered a green building technology, while it has also been viewed as the most effective method to realise lean construction [42], [47], [52]. Prefabrication enables lean construction through waste minimisation, improved construction productivity, improved efficiency, improved site safety, and improved quality [42], [52]. It simultaneously allows for green building to be realised, as it enables reduced energy consumption, reduced material waste, and reduced $\mathrm{CO}_{2}$ emissions [16], [48], [50]. This synergistic relationship that prefabricated construction and components create allows the sustainability triple bottom line to be realised. The literature, however, emphasised the importance of considering the limitations of prefabricated construction [34], [52-53]. The need to improve the process of prefabricated construction was emphasised, as it has the potential to play a significant role in improving sustainable developments in the future [34], [52]. This implies that there is a need for research into how prefabricated construction has improved, and how it potentially contributes to realising sustainable development goals.

\subsection{Operational phase}

Simultaneously incorporating lean construction and green building practices into the operational phase of the building enables an improved workplace environment for occupants, enhanced safety, minimised operational waste, and improved building maintenance and performance [16], [18], [47], [54-56].

\subsection{Demolition and deconstruction phase}

When lean construction and green building thinking are applied to the demolition and deconstruction phase, it is significantly dependent on the considerations from the previous phases [33]. The use of prefabricated construction and of recyclable and reusable materials had been considered at the design stage, through design for demolition or deconstruction (DfD) principles [33-34], [37]. The incorporation of 
lean construction significantly minimises waste, while green building principles are applied through the incorporation of recyclable and reusable materials. The literature also highlighted that there is a significantly small amount of research being completed in this phase, compared with the other phases of the development. Opportunities for future research for the application of lean and green in this phase are thus opened up.

\subsection{Building information modelling (BIM)}

Building information modelling (BIM) models and analysis are important in facilitating lean construction and green building in every phase of the development. BIM plays a significant role in allowing the two concepts to work together seamlessly across all stages of the development. BIM can be used in the design, construction, operational, and demolition phases, allowing an improved visualisation throughout each stage. The literature constantly highlighted how BIM is fundamentally woven into the fabric of both lean construction and green building practices [37], [46], [48], [54-55].

\subsection{The lean supply chain}

Incorporating green building principles into the lean supply chain, particularly when selecting suppliers and choosing materials, is key [57]. Interestingly, the review revealed that there is a great need for research into the application of lean construction and green building and their integration together at a supply chain level, particularly with supplier selection and materials.

\subsection{Emergent themes}

A number of unanticipated results emerged. The first was that the application of lean construction in practice may have a significantly negative effect on the health of workers through the number of motions and tasks required [16]. However, it was found in a later study that lean, from a social perspective, can improve health and safety when applied in practice owing to the improved work environment that is created and the accurate processes used in handling materials [18]. Thus there is a need for long-term analysis of the health implications for workers.

The next unexpected finding was that, initially, the just-in-time (JIT) delivery system of prefabricated components was deemed not to be an environmentally friendly delivery system, as JIT requires multiple trips to the site, which increase $\mathrm{CO}_{2}$ emissions when transporting [44]. However, more recent literature shows that JIT can greatly enhance the sustainability of lean supply practices [50]. Assessing the sustainability of JIT provides a potential gap for research to be conducted.

It was interesting to discover that the integration of BIM and geographical information improves utility and asset management, and optimises concrete truck mixer routes to minimise emissions and improve delivery time, while also improving site feasibility analysis [58-59], [37].

The incorporation of information technology (IT) and the Internet of Things (IOT) into making prefabricated construction leaner and more efficient was found to be emerging in the literature [42]. It is inevitable that the research into the application of Fourth Industrial Revolution principles in assisting lean construction and green building will increase exponentially.

\section{CONCLUSION}

In conclusion, this paper, using a systematic literature review, structurally and methodically explored the synergies between green building and lean construction, and how those synergies can enhance sustainable development practices. The paper provided strong evidence, using 68 articles from the academic literature, to support the notion that synergies do exist between the two concepts; and how these two concepts, in unison, can enhance sustainable development practices, despite the need for a practical implementation in a South African context.

This paper can greatly assist industry, both theoretically and practically. From a theoretical perspective, a systematic review of the academic literature has been provided that clearly highlighted the synergies between lean construction and green building, and how that helps to achieve more sustainable development. The paper also has practical implications, as it has provided suggestions to practitioners who are looking to implement certain tools, techniques, and practices from both green building and lean construction, and how their interaction can improve the way they carry out construction activities. It also provides practitioners with information on how green building and lean construction interact in each unique phase of a development, providing the practitioner with a more holistic view when developing. 


\subsection{Limitations}

A potential limitation of the paper is that the level of applicability of the two working concepts together in the South African context would need to be addressed further, as the local environment has its own practices, limitations, and barriers. This may affect the validity of the findings; however, many articles included studies that were done in developing nations, which may improve the applicability to the South African context.

\subsection{Further research opportunities}

Multiple research opportunities have been recommended in the findings section, but there are several that are directly related to the paper.

The first opportunity for further research would be to apply the above results in a practical local context. This could be done using a case study approach in a South African context, where both green building techniques and technologies, together with lean practices and principles, are being implemented and used in a development, from the preparation and design phase, through into the construction, operational, and demolition phases. The sustainability can then be measured against a matrix. The sustainability findings could then be compared against a development that has not implemented green building or lean construction practices. This comparison of the two would allow the theory to be put into practice, and would allow baseline measurements of how lean and green can improve sustainable development practices.

Second, research could be conducted on the implementation of green building and lean construction practices in each of the individual stages of the lifecycle of a building, particularly in a South African context.

Other opportunities for research include: investigating the interaction of green building and lean construction in the deconstruction and demolition phase of the development; conducting both qualitative and quantitative research into the supply chain interactions of green building and lean construction; and analysing the sustainability of the lean construction concept of JIT.

\section{REFERENCES}

[1] Bajjou, M.S. \& Chafi, A. 2018. A conceptual model of lean construction: A theoretical framework. Malaysian Construction Research Journal, 26, pp. 67-86. Available at: https://www.scopus.com/inward/record.uri?eid=2s2.0-85061550140\&partnerID=40\&md5=208447467d8a7d98c8356dab5950665d [Accessed 9 July 2019].

[2] Abanda, F.H., Tah, J.H.M. \& Cheung, F.K.T. 2017. BIM in off-site manufacturing for buildings. Journal of Building Engineering, 14, pp. 89-102. Available at: https://doi.org/10.1016/j.jobe.2017.10.002 [Accessed 13 July 2019].

[3] Waris, M., Shahir Liew, M., Khamidi, M.F. \& Idrus, A. 2014. Criteria for the selection of sustainable onsite construction equipment. International Journal of Sustainable Built Environment, 3, pp. 96-110. Available at: https: / / doi.org/10.1016/j.ijsbe.2014.06.002 [Accessed 8 July 2019].

[4] Oke, A., Aghimien, D., Aigbavboa, C. \& Musenga, C. 2019. Drivers of sustainable construction practices in the Zambian construction industry. Energy Procedia, 158, pp. 3246-3252. Available at: https://doi.org/10.1016/j.egypro.2019.01.995 [Accessed 8 July 2019].

[5] Wong, J.K.W. \& Zhou, J. 2015. Enhancing environmental sustainability over building life cycles through green BIM: A review. Automation in Construction, 57, pp. 156-165. Available at: https: //doi.org/10.1016/j.autcon.2015.06.003 [Accessed 25 June 2019].

[6] Aigbavboa, C., Oke, A. \& Momoti, T. 2016. Drivers and barriers of lean construction practice in South African construction industry. In: 2016 International Conference on Innovative Production and Construction. Perth. Available at: https://ujcontent.uj.ac.za/vital/access/manager/Repository/uj:21132 [Accessed 8 March 2018].

[7] Zhang, L., Wu, J. \& Liu, H. 2018. Turning green into gold: A review on the economics of green buildings. Journal of Cleaner Production, 172, pp. 2234-2245. Available at: https: / /www.sciencedirect.com/science/article/pii/S0959652617328615 [Accessed 10 March 2019].

[8] Teng, J., Mu, X., Wang, W., Xu, C. \& Liu, W. 2019. Strategies for sustainable development of green buildings. Sustainable Cities and Society, 44, pp. 215-226. Available at: https://www.sciencedirect.com/science/article/pii/S2210670718314677 [Accessed 8 March 2019 ].

[9] Zuo, J. \& Zhao, Z. 2014. Green building research - current status and future agenda: A review. Renewable and Sustainable Energy Reviews, 30, pp. 271-281. Available at: https: //www.sciencedirect.com/science/article/pii/S136403211300720X [Accessed 8 March 2019].

[10] World Green Building Council. 2019. What is green building? Available at: https://www.worldgbc.org/whatgreen-building [Accessed 12 March 2019].

[11] GBCSA. 2019. Building green: Why build green? Available at: https://gbcsa.org.za/about-gbcsa/building-green/ [Accessed 10 March 2019]. 
[12] Ahuja, R. 2012. Sustainable construction: Is lean green? In: ICSDEC 2012: Developing the frontier of sustainable design, engineering, and construction, Fort Worth, Texas. Available at:

https://www.researchgate.net/publication/268467641_Sustainable_Construction_Is_Lean_Green [Accessed 8 March 2019]

[13] Horman, M.J., Riley, D.R., Pulaski, M.H. \& Leyenberger, C. 2004. Lean and green: Integrating sustainability and lean construction. In: Building for the future, The 16th CIB World Building Congress, 2004, Rotterdam, Netherlands. Available at: http://www.irbnet.de/daten/iconda/CIB9767.pdf [Accessed 8 March 2019].

[14] Kulahcioglu, T., Dang, J. \& Toklu, C. 2012. A 3D analyzer for BIM-enabled life cycle assessment of the whole process of construction. HVAC\&R Research, 18, pp. 283-293. Available at: https://doi.org/10.1080/10789669.2012.634264 [Accessed 13 July 2019].

[15] Waris, M., Shahir Liew, M., Khamidi, M.F. \& Idrus, A. 2014. Criteria for the selection of sustainable onsite construction equipment. International Journal of Sustainable Built Environment, 3, pp. 96-110. Available at: https://doi.org/10.1016/j.ijsbe.2014.06.002 [Accessed 8 July 2019].

[16] Nahmens, I. \& Ikuma, L.H. 2012. Effects of lean construction on sustainability of modular homebuilding. Journal of Architectural Engineering, 18, pp. 155-163. Available at: https://ascelibrary.org/doi/abs/10.1061/\%28ASCE\%29AE.1943-5568.0000054 [Accessed 5 July 2019].

[17] Ahn, Y.H., Jung, C.W., Suh, M. \& Jeon, M.H. 2016. Integrated construction process for green building. In: Procedia Engineering, ICSDEC - Integrating Data Science, Construction and Sustainability, 145, pp. 670-676. Available at: https://doi.org/10.1016/j.proeng.2016.04.065 [Accessed 8 July 2019].

[18] Carvajal-Arango, D., Bahamón-Jaramillo, S., Aristizábal-Monsalve, P., Vásquez-Hernández, A. \& Botero, L.F.B. 2019. Relationships between lean and sustainable construction: Positive impacts of lean practices over sustainability during construction phase. Journal of Cleaner Production, 234, pp.1322-1337. Available at: https://doi.org/10.1016/j.jclepro.2019.05.216 [Accessed 8 July 2019].

[19] Xiao, Y. \& Watson, M. 2017. Guidance on conducting a systematic literature review. Journal of Planning Education and Research, 39(1) pp. 1-20. Available at: https://doi.org/10.1177/0739456X17723971 [Accessed 8 March 2019].

[20] Ham-Baloyi, W.T. \& Jordan, P. 2016. Systematic review as a research method in postgraduate nursing education. Health SA Gesondheid, 21, pp. 120-128. Available at: https: / /www.sciencedirect.com/science/article/pii/S1025984815000228 [Accessed 8 March 2019$].$

[21] Fink, A. 2005. Conducting research literature reviews: From the Internet to paper. $2^{\text {nd }}$ ed. Thousand Oaks, California: Sage Publications. Available at: https://searchworks.stanford.edu/view/6208979 [Accessed 13 July 2019].

[22] Okoli, C. \& Schabram, K. 2010. A guide to conducting a systematic literature review of information systems research. Working Papers on Information Systems, 10(26), pp. 1-55. Available at: https://pdfs.semanticscholar.org/31dc/753345d5230e421ea817dd7dcdd352e87ea2.pdf [Accessed 13 July 2019$].$

[23] Gough, D., Oliver, S. \& Thomas, J. 2012. An introduction to systematic reviews. London: Sage.

[24] Badi, S. \& Murtagh,N. 2019. Green supply chain management in construction: A systematic literature review and future research agenda. Journal of Cleaner Production, 223, pp. 312-322. Available at: https: / /www.sciencedirect.com/science/article/pii/S0959652619308236 [Accessed 28 July 2019].

[25] Jahan, N., Naveed, S., Zeshan, M. \& Tahir, M.A. 2016. How to conduct a systematic literature review: A narrative review. Cureus, 8(11) pp. 1-8. Available at: https://www.ncbi.nlm.nih.gov/pmc/articles/PMC5137994/ [Accessed 8 March 2019].

[26] Mann, K., Gordon, J. \& Macleod, A. 2007. Reflection and reflective practice in health professions education: A systematic review. Advances in Health Sciences Education, 14 (4). Available at: https: / /link.springer.com/article/10.1007/s10459-007-9090-2 [Accessed 19 March 2019].

[27] Simabanegavi, P., Shani, Z., Watkins, J. \& Ramruthan, K. 2019. Making rental housing in the gap-market more affordable through green building technology. In: CIBD 2019: The Construction Industry in the Fourth Industrial Revolution, Construction Industry Development Board Postgraduate Research Conference, Johannesburg, South Africa, 10 August 2019, pp. 241-251. Available at: https://link.springer.com/chapter/10.1007/978-3-030-265281_24 [Accessed 28 August 2019].

[28] Zotero. 2019. About. Available at: https://www.zotero.org/ [Accessed 10 September 2019].

[29] QSR International. 2019. What is NVivo? Available at: https://www.qsrinternational.com/nvivo/what-is-nvivo [Accessed 28 August 2019].

[30] Saldaña, J. 2015. The coding manual for qualitative researchers. $2^{\text {nd }}$ ed. London: Sage. Available at: https://uk.sagepub.com/en-gb/eur/the-coding-manual-for-qualitative-researchers/book243616 [Accessed 10 September 2019].

[31] Lucas, P.J., Baird, J., Arai, L., Law, C. \& Roberts, H.M. 2007. Worked examples of alternative methods for the synthesis of qualitative and quantitative research in systematic reviews. BMC Medical Research Methodology, 7(4). pp. 1-7 Available at: https://bmcmedresmethodol.biomedcentral.com/articles/10.1186/1471-2288-7-4 [Accessed 28 August 2019].

[32] Popay, J., Roberts, H., Sowden, A., Petticrew, M., Arai, L., Rodgers, M., Britten, N., Roen, K. \& Duffy, S. 2006. Guidance on the conduct of narrative synthesis in systematic reviews. A product from the ESRC methods programme. [ebook] Lancaster University. Available at:

https://www.researchgate.net/profile/Mark_Rodgers4/publication/233866356_Guidance_on_the_conduct_of_na rrative_synthesis_in_systematic_reviews_A_product_from_the_ESRC_Methods_Programme/links/02e7e5231e8f 3a

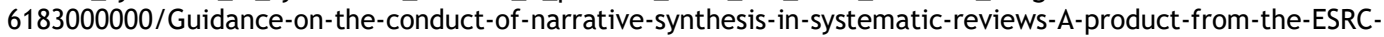
Methods-Programme.pdf [Accessed 6 March 2019]. 
[33] Ajayi, S.O. \& Oyedele, L.0. 2018. Critical design factors for minimising waste in construction projects: A structural equation modelling approach. Resources, Conservation and Recycling, 137, pp. 302-313. Available at: https://doi.org/10.1016/j.resconrec.2018.06.005 [Accessed 23 June 2019].

[34] Jaillon, L. \& Poon, C.S. 2014. Life cycle design and prefabrication in buildings: A review and case studies in Hong Kong. Automation in Construction, 39, pp. 195-202. Available at: https://doi.org/10.1016/j.autcon.2013.09.006 [Accessed 28 July 2019].

[35] Lu, Y., Wu, Z., Chang, R. \& Li, Y. 2017. Building information modeling (BIM) for green buildings: A critical review and future directions. Automation in Construction, 83, pp. 134-148. Available at: https: / /doi.org/10.1016/j.autcon.2017.08.024 [Accessed 8 July 2019].

[36] Jagannathan, M., Kamma, R.C., Renganaidu, V. \& Ramalingam, S. 2018. Enablers for sustainable lean construction in India. In: International Group of Lean Construction, 26th Annual Conference of the International Group for Lean Construction: Evolving Lean Construction Towards Mature Production Management Across Cultures and Frontiers, Chennai, India, 2018, pp. 910-922. Available at: https://doi.org/10.24928/2018/0247 [Accessed 9 July 2019].

[37] Wong, J.K.W. \& Zhou, J. 2015. Enhancing environmental sustainability over building life cycles through green BIM: A review. Automation in Construction, 57, pp. 156-165. Available at: https: //doi.org/10.1016/j.autcon.2015.06.003 [Accessed 25 June 2019].

[38] El-Sawalhi, N., Taber, B.M. \& Al Shukri, A. 2018. Towards lean and green thinking in construction projects at Gaza Strip. Organisation Technology and Management in Construction, 10, pp. 1827-1838. Available at: https://doi.org/10.2478/otmcj-2018-0011 [Accessed 25 June 2019].

[39] El-Reifi, M.H. \& Emmitt, S. 2013. Perceptions of lean design management. Architectural Engineering and Design Management, 9, pp. 195-208. Available at: https://doi.org/10.1080/17452007.2013.802979 [Accessed 27 June 2019].

[40] Jamil, A.H.A. \& Fathi, M.S. 2016. The integration of lean construction and sustainable construction: A stakeholder perspective in analysing sustainable lean construction strategies in Malaysia. Procedia Computer Science, 100, pp. 634-643. Available at: https://doi.org/10.1016/j.procs.2016.09.205 [Accessed 3 July 2019].

[41] Sonego, M., Echeveste, M.E.S. \& Galvan D.H. 2018. The role of modularity in sustainable design: A systematic review. Journal of Cleaner Production, 176, pp. 196-209. Available at: https://doi.org/10.1016/j.jclepro.2017.12.106 [Accessed 26 July 2019].

[42] Xu, G., Chen, C.H., Li, M. \& Wei, Y. 2018. Cloud asset enabled integrated loT platform for lean prefabricated construction. Automation in Construction, 93, pp. 123-134. Available at: https: //doi.org/10.1016/j.autcon.2018.05.012 [Accessed 6 July 2019].

[43] Tauriainen, M., Marttinen, P., Dave, B. \& Koskela, L. 2016. The effects of BIM and lean construction on design management practices. Procedia Engineering, 164, pp. 567-574. Available at: https://doi.org/10.1016/j.proeng.2016.11.659 [Accessed 23 July 2019].

[44] Bae, J.W. \& Kim, Y.W. 2008. Sustainable value on construction projects and lean construction. Journal of Green Building, 3, pp. 156-167. Available at: https://doi.org/10.3992/jgb.3.1.156 [Accessed 25 June 2019].

[45] Ragheb, A., El-Shimy, H. \& Ragheb, G. 2016. Green architecture: A concept of sustainability. Procedia: Social and Behavioral Science, 216, pp. 778-787. Available at: https://doi.org/10.1016/j.sbspro.2015.12.075 [Accessed 3 August 2019].

[46] Lekan, A., Oluchi, E., Faith, O., Opeyemi, J., Adedeji, A. \& Rapahel, 0. 2018. Creating sustainable construction: Building informatics modelling and lean construction approach. Journal of Theoretical and Applied Information Technology, 96(10), pp. 3025-3035. Available at: http://www.jatit.org/volumes/Vol96No10/23Vol96No10.pdf [Accessed 7July 2019].

[47] Darko, A., Chan, A.P.C., Gyamfi, S., Olanipekun, A.O., He, B.-J. \& Yu, Y. 2017a. Driving forces for green building technologies adoption in the construction industry: Ghanaian perspective. Building Environment, 125, pp. 206-215. Available at: https://doi.org/10.1016/j.buildenv.2017.08.053 [Accessed 24 June 2019].

[48] Ahuja, R., Sawhney, A. \& Arif, M. 2017. Driving lean and green project outcomes using BIM: A qualitative comparative analysis. International Journal of Sustainable Built Environment, 6, pp. 69-80. Available at: https: / / doi.org/10.1016/j.ijsbe.2016.10.006 [Accessed 7 July 2019].

[49] Jeong, W., Chang, S., Son, J.W. \& Yi, J.-S. 2016. BIM-integrated construction operation simulation for just-intime production management. Sustainability, 8(11). pp.1-25 Available at: https://doi.org/10.3390/su8111106 [Accessed 9 July 2019].

[50] Babalola, O., Ibem, E.O. \& Ezema, I.C. 2019. Implementation of lean practices in the construction industry: A systematic review. Building and Environment, 148, pp. 34-43. Available at: https: //doi.org/10.1016/j.buildenv.2018.10.051 [Accessed 8 July 2019].

[51] Marhani, M.A., Jaapar, A., Bari, N.A.A. \& Zawawi, M. 2013. Sustainability through lean construction approach: A literature review. In: Procedia - Social and Behavioural Sciences, International Conference on Quality of Life,2013 Langkawi, pp. 90-99. Available at: https://doi.org/10.1016/j.sbspro.2013.07.182 [Accessed 7 June 2019]

[52] Tam, V.W.Y. \& Hao, J.J.L. 2014. Prefabrication as a mean of minimizing construction waste on site. International Journal of Construction Management, 14, pp. 113-121. Available at: https://doi.org/10.1080/15623599.2014.899129 [Accessed 26 June 2019].

[53] Abanda, F.H., Tah, J.H.M. \& Cheung, F.K.T. 2017. BIM in off-site manufacturing for buildings. Journal of Building Engineering, 14, pp. 89-102. Available at: https://doi.org/10.1016/j.jobe.2017.10.002 [Accessed 13 July 2019].

[54] Oti, A.H., Kurul, E., Cheung, F. \& Tah, J.H.M. 2016. A framework for the utilization of building management system data in building information models for building design and operation. Automation in Construction, 72, pp. 195-210. Available at: https://doi.org/10.1016/j.autcon.2016.08.043 [Accessed 21 July 2019]. 
[55] Lu, Y., Wu, Z., Chang, R. \& Li, Y. 2017. Building information modeling (BIM) for green buildings: A critical review and future directions. Automation in Construction, 83, pp. 134-148. Available at: https://doi.org/10.1016/j.autcon.2017.08.024 [Accessed 8 July 2019].

[56] Ahn, Y.H., Jung, C.W., Suh, M. \& Jeon, M.H. 2016. Integrated construction process for green building. In: Procedia Engineering, ICSDEC - Integrating Data Science, Construction and Sustainability, 145, pp. 670-676. Available at: https://doi.org/10.1016/j.proeng.2016.04.065 [Accessed 8 July 2019].

[57] Ahmed, M.E.A.M. \& Wong, L.S. 2018. Assessment of lean construction practice at selected construction sites in Klang Valley. International Journal of Engineering and Technology, 7, pp. 125-130. Available at: https: //doi.org/10.14419/ijet.v7i4.35.22340 [Accessed 9 July 2019].

[58] Singh, J., Mangal, M. \& Cheng, J.C.P. 2017. It for lean construction - A survey in India. In: International Group of Lean Construction, 25th Annual Conference of the International Group for Lean Construction,2017 Heraklion, Greece, pp. 119-126. Available at: https://doi.org/10.24928/2017/0321 [Accessed 9 July 2019].

[59] Yin, X., Liu, H., Chen, Y. \& Al-Hussein, M. 2019. Building information modelling for off-site construction: Review and future directions. Automation in Construction, 101, pp. 72-91. Available at: https: //doi.org/10.1016/j.autcon.2019.01.010 [Accessed 23 June 2019].

[60] Drucker, A.M., Fleming, P. \& Chan, A.W. 2016. Research techniques made simple: Assessing the risk of bias in systematic literature reviews. Journal of Investigative Dermatology, 136(11). pp. 109-114 Available at: https://www.sciencedirect.com/science/article/pii/S0022202X16323569 [Accessed 28 July 2019]. 